\title{
Serum S100A8 and S100A9 Enhance Innate Immune Responses in the Pathogenesis of Baker's Asthma
}

\author{
Duy Le Pham ${ }^{\mathrm{a}}$ b Moon-Guyng Yoon ${ }^{\mathrm{a}}$ Ga-Young Ban ${ }^{\mathrm{a}}$ Seung-Hyun Kim ${ }^{\mathrm{a}}$ \\ Mi-Ae Kim ${ }^{c}$ Young-Min Ye ${ }^{a}$ Yoo Seob Shin ${ }^{a}$ Hae-Sim Park ${ }^{a, b}$ \\ a Department of Allergy and Clinical Immunology, Ajou University School of Medicine, and bepartment \\ of Biomedical Sciences, Graduate School, Ajou University, Suwon, and 'Department of Allergy and Clinical \\ Immunology, CHA Bundang Medical Center, Seongnam, South Korea
}

\section{Key Words}

Baker's asthma - Genetic polymorphisms · Innate immune responses $\cdot$ Occupational exposure $\cdot \mathbf{S 1 0 0}$ proteins

\begin{abstract}
Background: S100A8 and S100A9 can be produced by lipopolysaccharide-stimulated granulocytes and provoke an innate immune-mediated airway inflammation. Involvement of S100A8 and S100A9 has been implicated in asthma. To further understand the role of S100A8 and S100A9 during innate immune responses in baker's asthma, we investigated the associations of serum S100A8 and S100A9 with exposure to bakery allergens and polymorphisms of the Toll-like receptor 4 (TLR4) gene. Methods: Totally, 381 bakery workers and 100 unexposed healthy controls were recruited. Skin prick tests for bakery allergens were performed. Serum levels of S100A8, S100A9, myeloperoxidase (MPO), tumor necrosis factor (TNF)- $a$, and interleukin (IL)-8 were measured using ELISA. Predictive values of serum S100A8 and S100A9 in bakery workers were evaluated by receiver-operating character-
\end{abstract}

istic (ROC) curves. Polymorphisms of TLR4 $-2027 \mathrm{~A} \rightarrow \mathrm{G}$ and $-1608 \mathrm{~T} \rightarrow \mathrm{C}$ were genotyped. Results: Higher serum levels of S100A8 and S100A9 were noted in bakery workers compared to the normal controls ( $p<0.001$ ); however, no significant differences were noted according to work-related symptoms. The area under the ROC curve of serum S100A8 was 0.886 for occupational exposure $(p<0.001)$. The TLR4 $-1608 C C$ genotype was significantly associated with a higher serum S100A8 level $(p=0.025)$. Serum S100A8 and S100A9 levels were correlated with serum levels of MPO $(r=0.396$ and 0.189 , respectively), TNF- $a(r=0.536$ and 0.280 , respectively), and IL-8 $(r=0.540$ and 0.205 , respectively; $p<0.001$ for all). Conclusion: S100A8 and S100A9 are involved in innate immune responses under the regulation of TLR4 polymorphisms in baker's asthma pathogenesis. Serum S100A8 could be a potential biomarker for predicting occupational exposure to wheat flour in bakery workers.

(c) 2016 S. Karger AG, Basel

D.L.P. and M.-G.Y. contributed equally to this work.

\section{KARGER 125}

(c) 2016 S. Karger AG, Base

$1018-2438 / 16 / 1682-0138 \$ 39.50 / 0$

E-Mail karger@karger.com

www.karger.com/iaa
Correspondence to: Prof. Hae-Sim Park

Department of Allergy and Clinical Immunology

Ajou University School of Medicine, San-5, Woncheon-dong, Youngtong-gu

Suwon 442-721 (South Korea)

E-Mail hspark@ajou.ac.kr 


\section{Introduction}

Baker's asthma is one of the most frequently found occupational asthma types worldwide. In Korea, $5-10 \%$ of bakery workers have been reported to have work-related asthma [1]. We previously demonstrated that $13.5 \%$ of bakery workers had work-related lower respiratory symptoms and $31.6 \%$ had work-related rhinitis symptoms [2]. It has been suggested that both adaptive and innate immune responses have been involved in the pathogenesis of baker's asthma. Exposure to bakery allergens can elicit sensitization resulting in the production of specific IgG and $\mathrm{IgE}$ antibodies [3]. Moreover, innate immune responses, including activated neutrophils and macrophages, could contribute to airway inflammation induced by flour dust exposure [4].

S100A8 and S100A9 are $\mathrm{Ca}^{2+}$ - and $\mathrm{Zn}^{2+}$-binding proteins of the S100 family, which comprises a group of endogenous DAMP (damage-associated molecular pattern) molecules $[5,6]$. S100A8 and S100A9 could be secreted by neutrophils, activated monocytes, and macrophages in the form of homo- or heterodimers. In heterodimer complexes, the S100A8 subunit has a major reactive function, while the S100A9 subunit has a modulatory role [5]. S100A 8 and S100A9 have long been considered biomarkers for several inflammatory diseases, such as rheumatoid arthritis, juvenile idiopathic arthritis, and inflammatory bowel disease [7]. Lee et al. [8] have recently found a greater S100A9 protein expression in sputum neutrophils of uncontrolled severe asthma patients compared to controlled asthmatics. Moreover, S100A8 and S100A9 can activate human airway epithelial cells to induce the production of mucin 5AC [6], a glycoprotein highly secreted from asthmatic airway epithelium $[9,10]$. These findings indicate a role of S100A8 and S100A9 proteins in asthma; however, their association with baker's asthma has not been determined yet.

Toll-like receptor (TLR) 4 is a receptor for both S100A8 and S100A9 proteins [5]. By binding to TLR4, S100A8 and S100A9 can activate the NF- $\mathrm{BB}$ pathway, leading to the production of various proinflammatory cytokines that contribute to asthma pathogenesis $[6,11]$. Concomitantly, TLR4 can be activated by lipopolysaccharide (LPS), an endotoxin found in bakery flour dust, leading to the activation of monocytes, followed by the production of S100A8/S100A9 [7]. In our previous study, TLR4 genetic polymorphisms at $-2027 \mathrm{~A} \rightarrow \mathrm{G}$ and $-1608 \mathrm{~T} \rightarrow \mathrm{C}$ have been found to be associated with work-related symptoms (WRS) in bakery workers, indicating the involvement of innate immune responses in baker's asthma [12].
Based on these finding, we aimed to evaluate the role of innate immune responses by measuring serum levels of S100A8 and S100A9 in bakery workers compared to unexposed healthy subjects, and to investigate the associations of the two S100 proteins with clinical parameters of baker's asthma and TLR4 gene polymorphisms.

\section{Methods}

\section{Study Subjects}

We recruited 381 bakery workers (occupationally exposed workers) from a single industrial site in Seongnam, South Korea, and 100 healthy subjects (unexposed controls) who had not been exposed to bakery allergens (including wheat flour extract, rye, yeast, egg, $\alpha$-amylase, and storage mites). A questionnaire was used to collect the personal history of bakery allergen exposure, WRS, including upper respiratory symptoms (nasal itching, runny nose, sneezing, or congestion) and lower respiratory symptoms (cough, sputum, shortness of breath, or wheezing), which worsened at work but improved after work or during holidays. Subjects who had current work-unrelated respiratory symptoms or chronic diseases, and those who were using immune-modulating medications, such as corticosteroids, were excluded from this study. Written informed consent was obtained from each of study participant. This study was approved by the Ajou University Institute Review Board.

\section{Skin Prick Tests and Measurement of Serum-Specific}

Antibodies to Wheat Flour

To determine the atopy status, all study subjects underwent skin prick tests (SPT) with common inhalant allergens, including mixtures of trees and grass, mugwort, ragweed, cat and dog fur, Dermatophagoides pteronyssinus, Dermatophagoides farinae, and Alternaria (Bencard, Bretford, UK). In addition, SPT with bakery allergens were performed in bakery workers, including wheat flour extract, rye, yeast (prepared as previously described [2]), egg (Bencard), a-amylase (from Aspergillus spp.; Sigma-Aldrich, St. Louis, Mo., USA), and storage mites (Tyrophagus putrescentiae; Allergopharma, Reinbek, Germany). Positive results of SPT were determined by the ratio of the mean wheal diameter of the allergen to histamine $\geq 1$. Atopy was considered 'present' if the study subject had more than one positive response to common inhalant allergens. Serum total IgE levels were measured using the ImmunoCAP system (ThermoFisher, Uppsala, Sweden). Serum specific IgE, IgG1, and IgG4 antibodies to wheat flour extracts were measured using ELISA as previously described [2].

\section{TLR4 Gene Genotyping}

The two single nucleotide polymorphisms (SNP) of the TLR4 gene, $-2027 \mathrm{~A} \rightarrow \mathrm{G}$ and $-1608 \mathrm{~T} \rightarrow \mathrm{C}$, were genotyped as previously described [12]. Briefly, genomic DNA was prepared from peripheral blood samples using a Puregene DNA purification kit (Qiagen, Germantown, Md., USA) and genotyped for the two SNP using the SNaPshot ddNTP primer extension method (Applied Biosystems, Foster City, Calif., USA). The primers used for amplification and extension have been described previously [12]. 
Table 1. Clinical characteristics of the study subjects

\begin{tabular}{|c|c|c|c|}
\hline & $\begin{array}{l}\text { Exposed workers } \\
(\mathrm{n}=381)\end{array}$ & $\begin{array}{l}\text { Unexposed controls } \\
(\mathrm{n}=100)\end{array}$ & $\mathrm{p}$ value \\
\hline Age, years & $34.92 \pm 7.68$ & $26.36 \pm 3.22$ & $<0.001$ \\
\hline Male gender, n (\%) & $216(56.7)$ & $67(67)$ & 0.062 \\
\hline Atopy, n/total n (\%) & $128 / 370(34.6)$ & $30 / 65(46.2)$ & 0.074 \\
\hline Working period, years & $3.98 \pm 3.49$ & n.a. & n.a. \\
\hline Work-related URS, n/total n (\%) & $49 / 373(13.1)$ & n.a. & n.a. \\
\hline Work-related LRS, n/total n (\%) & $28 / 376(7.4)$ & n.a. & n.a. \\
\hline $\mathrm{FEV}_{1}, \%$ of predicted & $94.61 \pm 12.72$ & n.a. & n.a. \\
\hline \multicolumn{4}{|l|}{ SPT results to baker's allergens, n (\%) } \\
\hline Wheat flour & $25(6.8)$ & n.a. & n.a. \\
\hline Rye & $9(2.4)$ & n.a. & n.a. \\
\hline Yeast & $11(3.0)$ & n.a. & n.a. \\
\hline Egg & $5(1.3)$ & n.a. & n.a. \\
\hline a-Amylase & $1(0.2)$ & n.a. & n.a. \\
\hline Storage mites & $11(3.0)$ & n.a. & n.a. \\
\hline Total IgE, IU/ml & $227.49 \pm 425.1$ & n.a. & n.a. \\
\hline \multicolumn{4}{|l|}{ Specific Ig to wheat, n/total n (\%) } \\
\hline $\operatorname{IgE}$ & $24 / 380(6.3)$ & n.a. & n.a. \\
\hline IgG1 & $79 / 380(20.8)$ & n.a. & n.a. \\
\hline IgG4 & $55 / 380(14.5)$ & n.a. & n.a. \\
\hline Serum MPO, ng/ml & $139.04 \pm 80.43$ & $99.85 \pm 91.79$ & $<0.001$ \\
\hline Serum IL-8, pg/ml & $296.43 \pm 343.9$ & $29.72 \pm 82.1$ & $<0.001$ \\
\hline Serum TNF- $\alpha, \mathrm{pg} / \mathrm{ml}$ & $47.77 \pm 71.6$ & $3.31 \pm 5.4$ & $<0.001$ \\
\hline
\end{tabular}

$\mathrm{FEV}_{1}=$ Forced expiratory volume in $1 \mathrm{~s} ; \mathrm{LRS}=$ lower respiratory symptom; $\mathrm{n}=$ number of patients; $\mathrm{n} . \mathrm{a} .=\mathrm{not}$ available; URS = upper respiratory symptom. $\mathrm{p}$ values were obtained by $\chi^{2}$ test for categorical variables and Student's t test for continuous variables.

ELISA to Measure Serum Levels of S100A8, S100A9,

Myeloperoxidase, Tumor Necrosis Factor- $\alpha$, and Interleukin-8

Serum levels of S100A8 and S100A9 were measured using commercial ELISA kits (R\&D Systems, Minneapolis, Minn., USA) according to the manufacturer's protocol. The lower detection limit of both S100A8 and S100A9 by the ELISA kits was $31.25 \mathrm{pg} / \mathrm{ml}$. Serum levels below the detection limit were adjusted to the lower limit of detection.

ELISA kits were used to measure serum levels of myeloperoxidase (MPO; Biocheck Inc., Forster City, Calif., USA), tumor necrosis factor (TNF)- $a$ (Pierce Biotechnology, Rockford, Ill., USA), and interleukin-8 (IL-8; Endogen, Woburn, Mass., USA) according to the manufacturers' protocols.

\section{Statistical Analysis}

We log-transformed the data of serum S100A8 and S100A9 levels prior to statistical analysis to correct their skewed distributions. Student's t test (for log-transformed data) or the MannWhitney $U$ test (for raw data) was used to compare the serum levels of S100A 8 and S100A9 between the two study groups or according to the clinical as well as genetic parameters. Predictive values of serum S100A8 and S100A9 were determined by the receiveroperating characteristic (ROC) curve. Pearson's correlation or Spearman's rank correlation coefficient was used to examine correlations of S100A8 and S100A9 with other parameters.
In genetic association analysis, the $\chi^{2}$ test with 1 degree of freedom was used to examine the frequency of each SNP in each gene for significant departure from the Hardy-Weinberg equilibrium. The haplotype block pattern was constructed using Haploview software version 4.2. Haplotypes that had a frequency of more than $5 \%$ were selected for statistical analysis. Differences in genotype and haplotype frequencies between the study groups were examined by logistic regression analysis with codominant, dominant, and recessive models after accounting for age and sex as covariates. General linear models were applied to compare serum levels of S100A8 and S100A9 according to genotype and haplotype distributions in the bakery workers.

All statistical analyses were performed with SPSS version 20.0.0 (SPSS, Chicago, Ill., USA), and $\mathrm{p}<0.05$ was considered statistically significant.

\section{Results}

\section{Characteristics of the Study Subjects}

Table 1 shows the demographic characteristics of the study subjects. Compared to the unexposed healthy controls, the bakery workers were significantly older $(\mathrm{p}<$ 


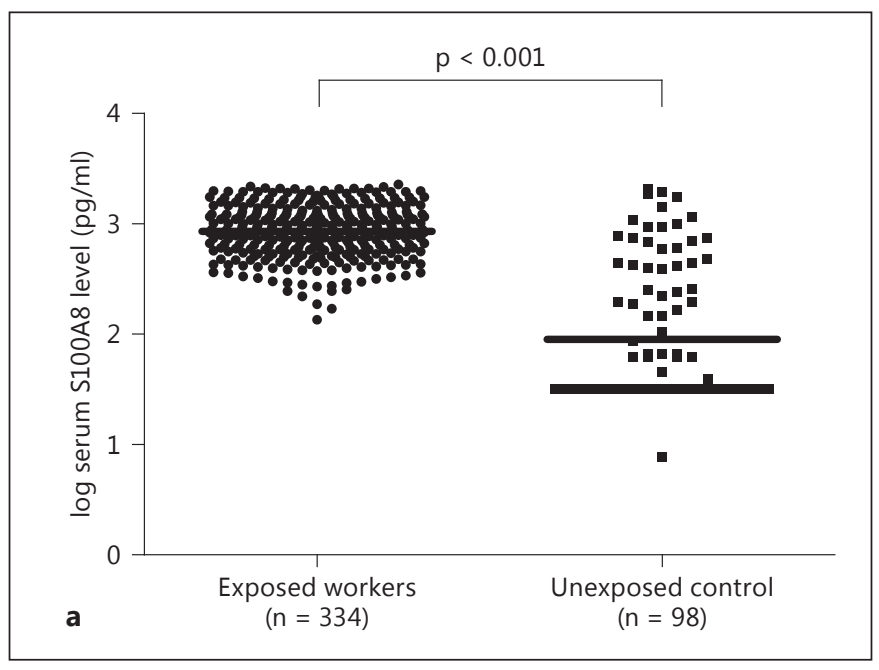

Fig. 1. Serum levels of S100A8 (a) and S100A9 (b) in occupationally exposed bakery workers and unexposed healthy controls; logtransformed data are shown. The horizontal lines in the middle of the dot plots indicate mean values. $\mathrm{p}$ values were obtained by independent Student's t test. c The correlation between serum S100A8 and S100A9 levels in bakery workers exposed to occupational allergens (Pearson's correlation coefficients were determined).

0.001 ) and had significantly higher serum levels of MPO, TNF- $\alpha$, and IL-8 $(\mathrm{p}<0.001)$. The mean duration of occupational exposure of the bakery workers was $3.98 \pm 3.49$ years. The frequencies of upper and lower respiratory WRS were 13.1 and $7.4 \%$, respectively. The prevalence of atopy to bakery allergens, including wheat flour, rye, yeast, egg, $\alpha$-amylase, and storage mites, as identified by SPT in the bakery workers, is shown in table 1.

\section{Increased Serum Levels of S100A8 and S100A9 in the Bakery Workers}

Serum S100A8 and S100A9 levels were highly elevated in a minor population of the study subjects, especially in bakery workers. Consequently, the serum levels of S100A8 and S100A9 had skewed distributions. Therefore, we performed $\log$ transformation of the two serum S100 protein
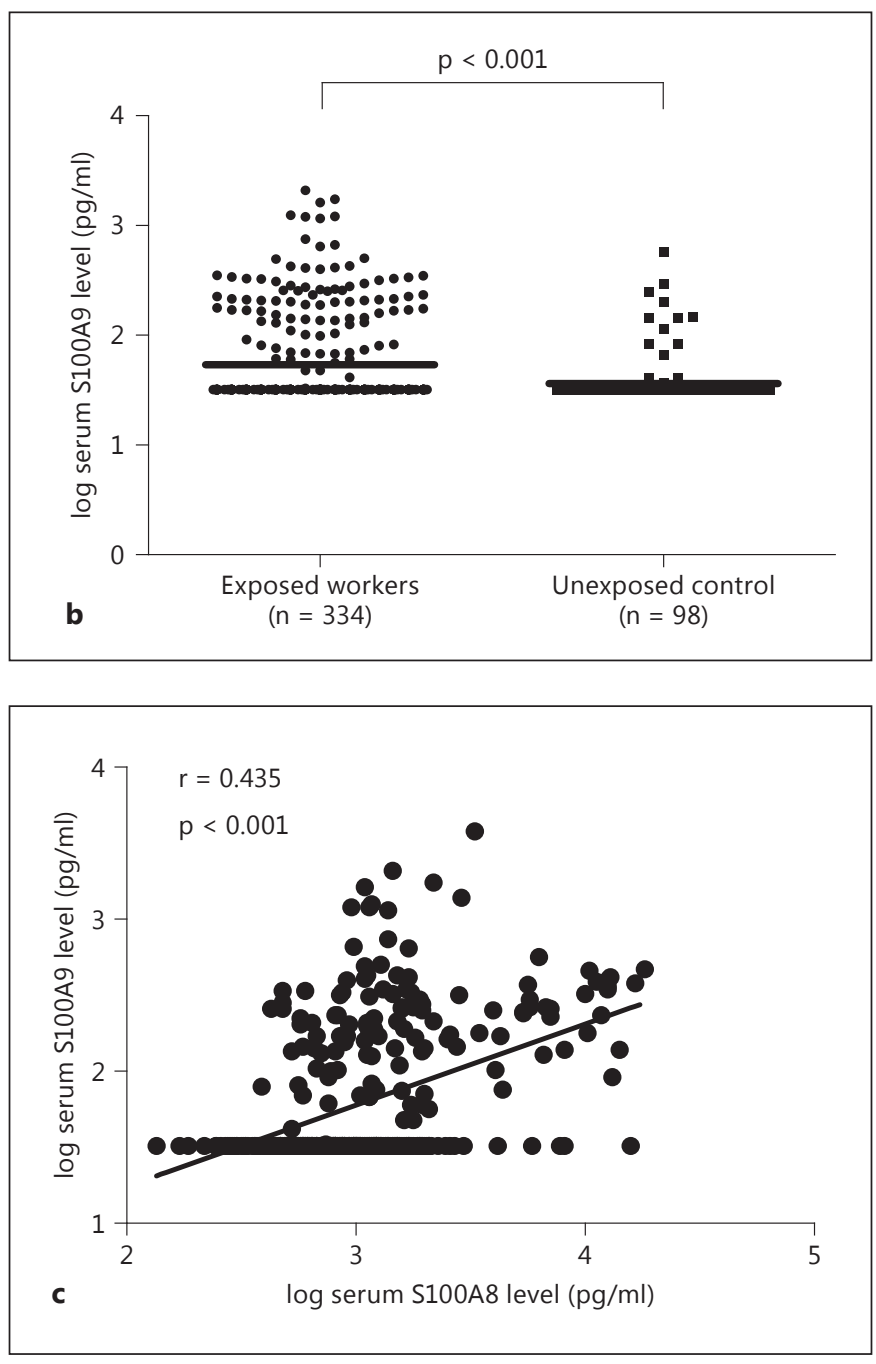

levels to achieve normal distributions. The log-transformed mean serum levels ( $\mathrm{pg} / \mathrm{ml}$ ) of S100A8 and S100A9 in the bakery workers were significantly higher than those of the unexposed healthy controls $(3.03 \pm 0.36$ vs. $1.99 \pm$ 0.67 and $1.79 \pm 0.45$ vs. $1.59 \pm 0.25$, respectively, $\mathrm{p}<0.001$ for both; fig. 1a, b). In addition, the raw mean serum levels of S100A 8 and S100A9 were significantly higher in the bakery workers than those in the unexposed healthy controls $(1,722.51 \pm 2,570.27$ vs. $507.52 \pm 1,984.57$ and 133.79 \pm 300.16 vs. $51.8 \pm 74.45 \mathrm{pg} / \mathrm{ml}$, respectively, $\mathrm{p}<0.001$ for both; online suppl. fig. S1A, B; for all online suppl. material, see www.karger.com/doi/10.1159/000441678). Additionally, there were significantly positive correlations between serum levels of S100A8 and S100A9 in both logtransformed ( $\mathrm{r}=0.435, \mathrm{p}<0.001$; fig. 1c) and raw data $(\mathrm{r}=0.418 ; \mathrm{p}<0.001$; online suppl. fig. $\mathrm{S} 1 \mathrm{C})$ among the 


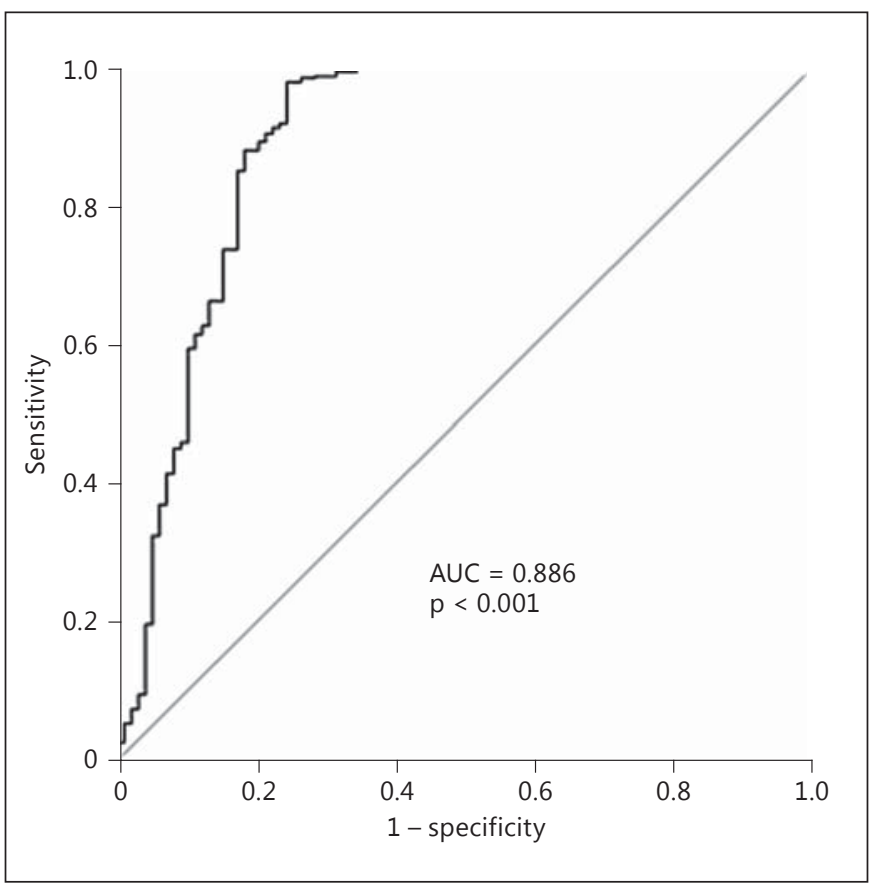

Fig. 2. Predictive values of serum S100A8 for occupational allergen exposure in bakery workers evaluated by the ROC curve method.

bakery workers. However, no significant differences were noted in both S100A8 and S100A9 levels according to the presence of WRS and SPT response to each bakery allergen (online suppl. table S1).

We evaluated the predictive values of serum S100A8 and S100A9 in bakery workers by the ROC curve method. The area under the ROC curve (AUC) of serum S100A8 (fig. 2) was 0.886 ( $p<0.001$ ); a cutoff value of $254.7 \mathrm{pg} / \mathrm{ml}$ provided a sensitivity of $98.4 \%$ and a specificity of $74 \%$ in the study population. The AUC of serum S100A9 was $0.610(\mathrm{p}=0.001)$, with $33.6 \%$ sensitivity and $89 \%$ specificity at a cutoff value of $41.19 \mathrm{pg} / \mathrm{ml}$ (data not shown).

\section{Associations of Serum S100A8 and S100A9 with} Several Serum Cytokines

There were significantly positive correlations ( $\mathrm{p}<$ 0.001 for all) in log-transformed serum levels of S100A8 and S100A9 with serum levels of MPO ( $\mathrm{r}=0.396$ and 0.189 , respectively; fig. $3 \mathrm{a})$, TNF- $\alpha(\mathrm{r}=0.536$ and 0.280 , respectively; fig. $3 \mathrm{~b})$, and IL- $8(\mathrm{r}=0.540$ and 0.205 , respectively; fig. 3c) among the study subjects. The correlations of raw serum levels of S100A8 and S100A9 with the other cytokines in the bakery worker group are shown in online supplementary figure S2.
Table 2. Frequency of TLR4 gene SNP alleles in bakery workers

\begin{tabular}{lllll}
\hline $\begin{array}{l}\text { TLR4 SNP } \\
\text { name }\end{array}$ & Chromosome & Location & MAF & $\begin{array}{l}\text { HWE } \\
\text { ( } \mathrm{p} \text { value) }\end{array}$ \\
\hline$-2027 \mathrm{~A} \rightarrow \mathrm{G}$ & 9 & Promoter & 0.387 & 0.847 \\
$-1608 \mathrm{~T} \rightarrow \mathrm{C}$ & 9 & Promoter & 0.267 & 0.787 \\
\hline
\end{tabular}

$\mathrm{HWE}=$ Hardy-Weinberg equilibrium; $\mathrm{MAF}=$ minor allele frequency.

\section{Associations of Serum S100A8 with TLR4 gene}

Polymorphisms

Table 2 shows the frequency of TLR $4-1608 \mathrm{~T} \rightarrow \mathrm{C}$ and $-2027 \mathrm{~A} \rightarrow \mathrm{G}$ polymorphisms in the bakery workers. The two TLR4 SNP did not depart significantly from the Hardy-Weinberg equilibrium ( $\mathrm{p}>0.05$ for all), with high pairwise linkage disequilibrium of the two TLR4 SNP $\left(\mathrm{D}^{\prime}=1\right.$ and $\left.\mathrm{r}^{2}=0.57\right)$. The three haplotypes HT1 (AT), HT2 (GC) and HT3 (GT) that were constructed from the two TLR4 SNP had frequencies of 61,26 , and $12 \%$ in the study population, respectively.

While TLR4 -2027A $\rightarrow \mathrm{G}$ was not significantly associated with serum levels of S100A8 or S100A9 (data not shown), the log-transformed serum level $(\mathrm{pg} / \mathrm{ml})$ of S100A8 in bakery workers carrying the TLR4 -1608CC genotype $(3.18 \pm 0.49)$ was significantly higher than in those carrying the $-1608 \mathrm{TT} / \mathrm{TC}$ genotype $(3.02 \pm 0.35$, $\mathrm{p}=0.025$; fig. $4 \mathrm{a}$ ); however, TLR4 $-1608 \mathrm{~T} \rightarrow \mathrm{C}$ polymorphisms were not associated with serum S100A9 levels. The bakery workers who carried HT2 (GC) had a significantly higher log-transformed serum level of S100A8 compared to those who did not $(3.18 \pm 0.49$ vs. $3.02 \pm$ $0.35, \mathrm{p}=0.025$; fig. 4b). Consistently, TLR4 $-1608 \mathrm{~T} \rightarrow \mathrm{C}$ polymorphisms as well as HT2 (GC) were significantly associated with raw serum level of S100A8 ( $p=0.004$ for both; online suppl. fig. S3).

\section{Discussion}

Involvement of adaptive immune responses in baker's asthma has long been studied; however, the role of innate immune responses has not yet been clearly elucidated. S100A8 and S100A9, belonging to the S100 protein family, have been found to be upregulated and secreted by various granulocytes, including neutrophils and macrophages, during innate immune responses [13]. These two proteins exhibit various proinflammatory effects, including leukocyte recruitment and cytokine production [5, 

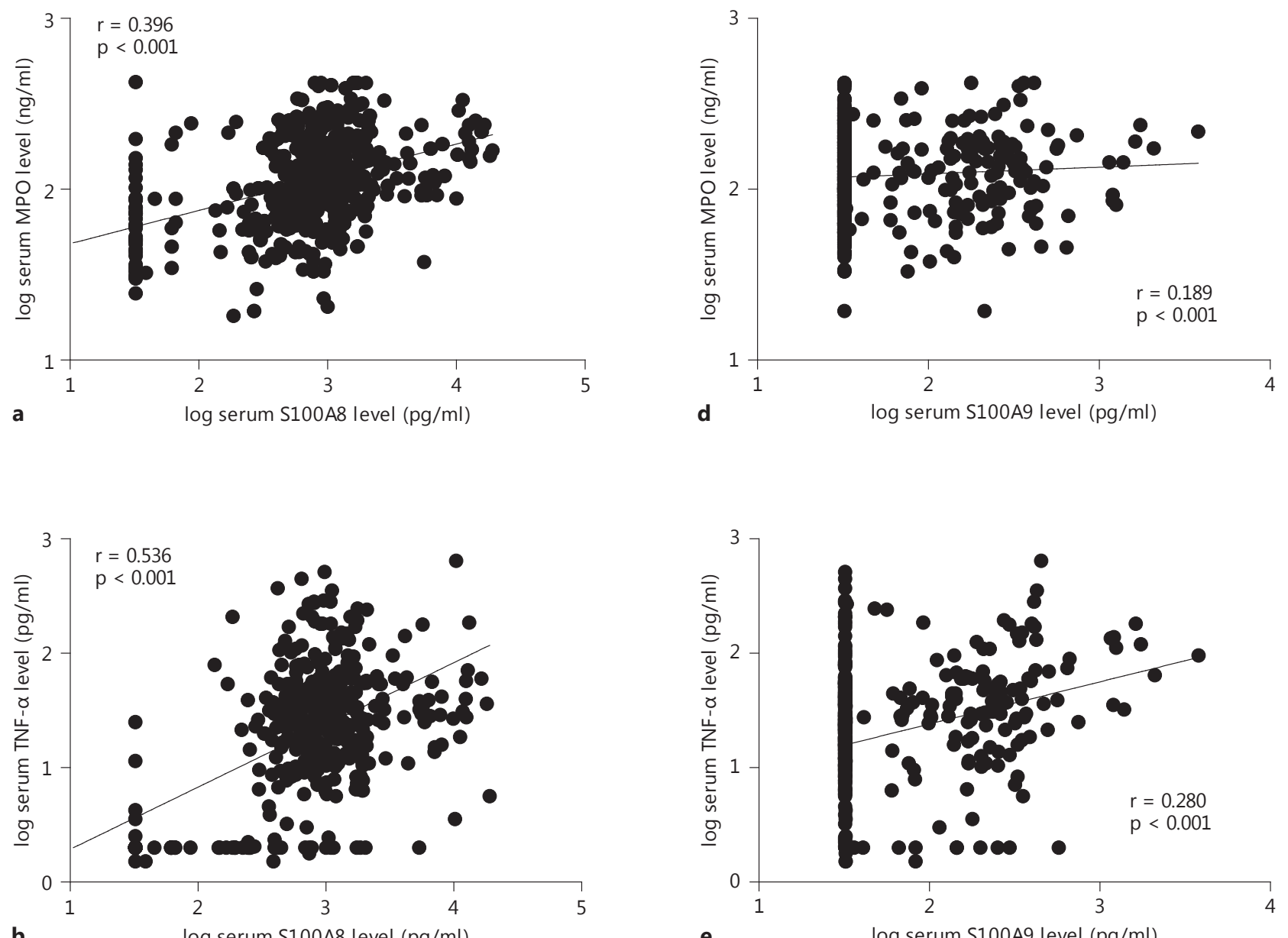

b $\quad \log$ serum S100A8 level $(\mathrm{pg} / \mathrm{ml})$
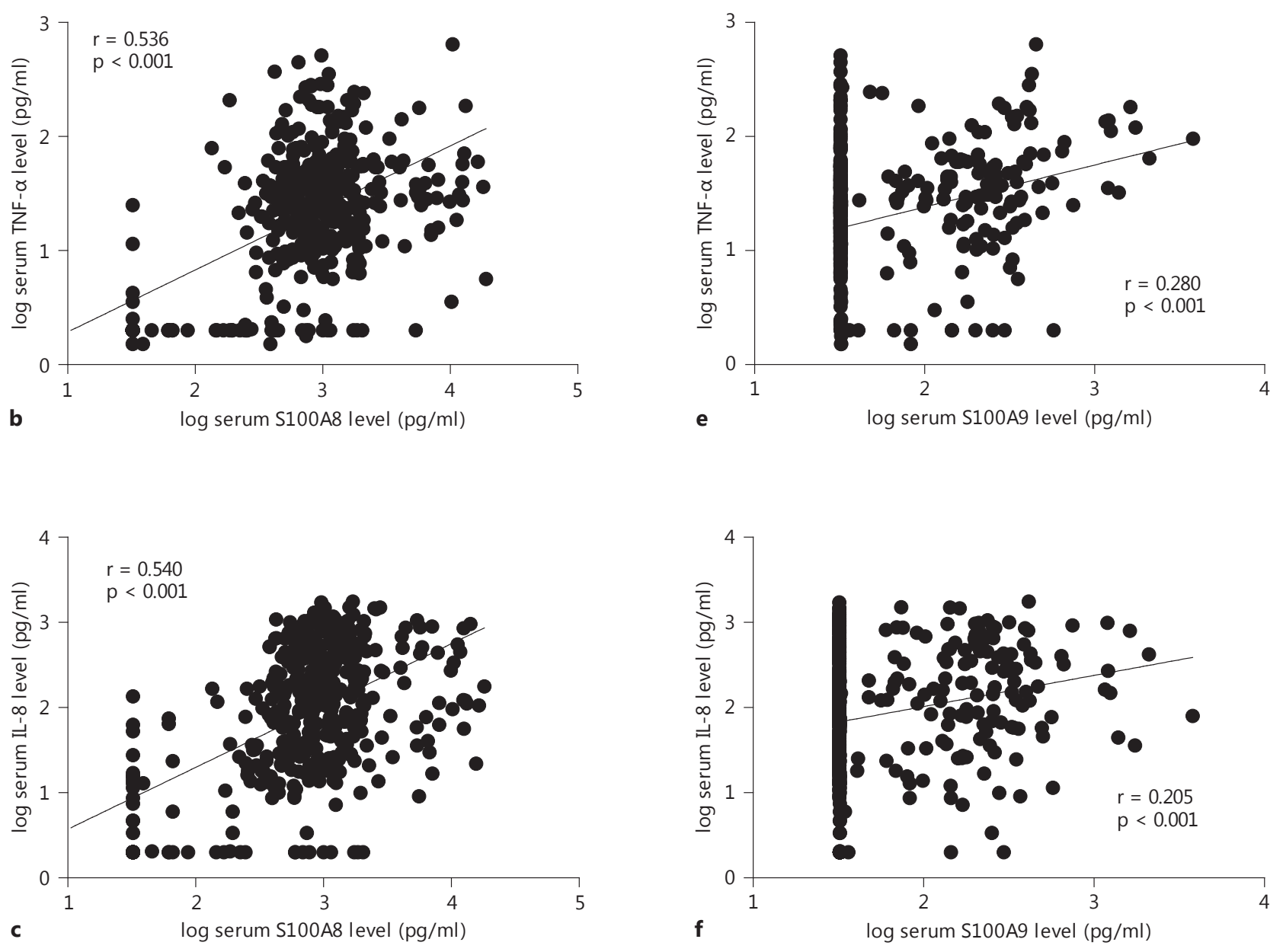

Fig. 3. Scatterplots showing correlations of serum S100A8 (a-c) and S100A9 levels (d-f) with serum MPO (a, d), TNF- $\alpha(\mathbf{b}, \mathbf{e})$, and IL-8 levels $(\mathbf{c}, \mathbf{f})$ in the study subjects; log-transformed data are shown. Pearson's correlation coefficients were calculated. 


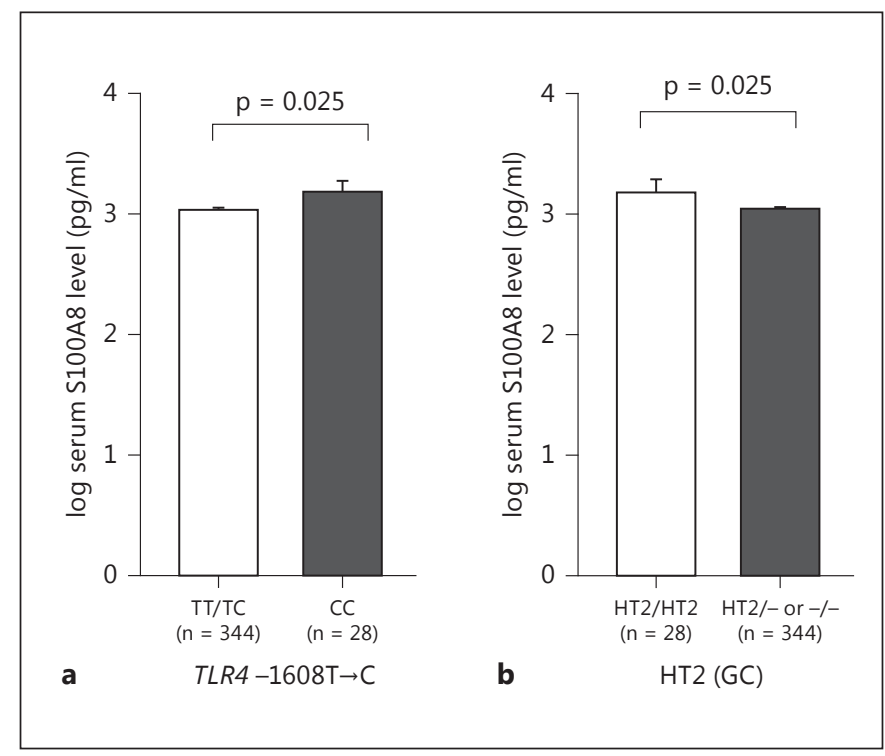

Fig. 4. Association of the serum S100A8 level with the TLR4 $-1608 \mathrm{~T} \rightarrow$ C polymorphism (a) and HT2 (GC) of TLR4 $-2027 \mathrm{~A} \rightarrow \mathrm{G}$ and $-1608 \mathrm{~T} \rightarrow \mathrm{C}(\mathbf{b})$; log-transformed data are shown. $\mathrm{p}$ values were obtained using general linear models adjusted for the covariates age and sex.

14]. S100A 8 and S100A9 have recently been implicated in the pathogenesis of asthma, although their roles are unclear $[5,13,15]$. The expression of S100A9 in peripheral blood mononuclear cells is elevated during asthma exacerbations [16], and sputum levels of S100A9 were increased in patients with severe neutrophilic asthma [8]. Based on these findings, we aimed to further elucidate the associations and roles of S100A8 and S100A9 proteins in innate immune responses in the pathogenesis of baker's asthma.

In the present study, we found significantly higher serum levels of both S100A8 and S100A9 in the bakery workers compared to the unexposed healthy controls. S100A8 and S100A9 are abundant proteins comprising approximately $20-45 \%$ of neutrophil cytosol, and both of them are chemoattractants for neutrophils and monocytes $[14,17,18]$. In a mouse model of baker's asthma, challenging with flour dust or flour extract elicited recruitment of neutrophils to inflammatory airways [4]. The recruitment and activation of neutrophils could lead to the increased secretion of S100A8 and S100A9. Furthermore, LPS, an endotoxin found in flour dust, could induce murine S100A8 mRNA expression in macrophages [17]. Consequently, S100A8 and S100A9 could mediate initial events in immune responses by priming and recruiting leukocytes. S100A8 and S100A9 are known to require cosecretion in a heterodimer complex to stabilize their activity, which may explain the positive correlation between the serum levels of the two S100 proteins observed in the present study.

When we evaluated the predictive values of the two S100 protein serum levels, serum S100A8 was a significant biomarker for bakery allergen exposure with an AUC of 0.886 , and had high sensitivity $(98.4 \%)$ as well as specificity (74\%) at the cutoff value of $254.7 \mathrm{pg} / \mathrm{ml}$. Even the highest sensitivity of the serum S100A9 test (33.6\%) obtained in the present study was inadequate for patient screening, but serum S100A9 may be a specific biomarker for bakery allergen exposure with a high specificity (89\%) at the cutoff value of $41.19 \mathrm{pg} / \mathrm{ml}$.

Nevertheless, no significant associations of these two S100 proteins with WRS as well as sensitization to baker's allergens were noted in the present study. Although in the bakery occupational exposure could elicit sensitizations to bakery allergens and WRS, those only occur in a small fraction of bakery workers $[19,20]$, which was consistently found in the present study (7.4 and $13.1 \%$, respectively). This common finding could explain the lack of associations among serum S100A8 as well as S100A9 levels and those parameters. Additionally, serum levels of S100A8 could be considered more sensitive than SPT in screening for occupational allergen exposure in bakers than available skin tests.

Both S100A8 and S100A9 could bind to and activate their receptor, TLR4, thereby amplifying endotoxin-induced inflammatory responses through several signaling transduction pathways, such as NF-kB, p38 MAPK, and MyD88 [7, 21]. In bakery workers, LPS in wheat flour could also interact with TLR4 to provoke airway inflammation [22]. Our previous study has shown that TLR4 expression is altered by TLR4 gene polymorphisms at $-2027 \mathrm{~A} \rightarrow \mathrm{G}$ and $-1608 \mathrm{~T} \rightarrow \mathrm{C}$, which are associated with WRS in bakery workers [12]. In the present study, we demonstrated significant associations of TLR4 -1608 CC genotype and HT1 (GC) of TLR $4-2027 \mathrm{~A} \rightarrow \mathrm{G}$ and $-1608 \mathrm{~T} \rightarrow \mathrm{C}$ with higher serum levels of S100A 8 but not S100A9. Detailed mechanisms how the TLR4 polymorphisms could affect S100A8 production in bakery workers are unclear. Several studies demonstrated that TLR4 activated by LPS, leading to the activation of the mitogen-activated protein kinase pathway, increased expression of S100A8 mRNA, but not S100A9 mRNA, in murine macrophages [23-25]. Those findings implicated the role of TLR4 in inducing S100A8 production. Collectively, we speculate that TLR4 promoter polymorphisms, which could affect TLR4 expression, could in- 
fluence the production and/or function of S100A8; however, underlying mechanisms remain to be identified.

MPO is an enzyme predominantly released by activated neutrophils during innate immune responses, which can generate reactive oxygen species causing damage to resident cells in the lung [26]. Neutrophils that are isolated from asthma patients produce higher levels of MPO compared to the healthy subjects [27]. In the present study, we found positive correlations of the serum MPO level with serum S100A8 and S100A9 levels. Consistent with our finding, positive correlations in serum levels of S100A8 and S100A9 with MPO have been reported in the lung of mice infected with Streptococcus pneumoniae [28]. Moreover, gene expression of MPO was found to be increased in transgenic mice that expressed human $S 100$ gene cluster (including S100A8, S100A9, and S10012) [29], indicating that activated neutrophils could concurrently produce high levels of S100A8, S100A9, and MPO. Additionally, S100A8/S100A9 in the combination with MPO could further increase the production of reactive oxygen species, which subsequently leads to tissue damage [30]. These findings suggest that S100A8, S100A9, and MPO could synergistically enhance inflammation in innate immune responses upon occupational allergen exposure in the bakery.

Both IL- 8 and TNF- $\alpha$ are proinflammatory mediators found to be increased in the sera of asthmatics during innate immune responses [31, 32]. In the present study, we found positive correlations of IL- 8 as well as TNF- $\alpha$ serum levels with serum S100A8 and S100A9 levels. S100A8/ S100A9 has been found to stimulate airway epithelial cells and monocytes, and in turn to produce IL- 8 as well as TNF- $\alpha[33,34]$. Concomitantly, the expression ofS100A8/ S100A9 heterodimers by monocytes and macrophages is associated with the secretion of TNF- $\alpha$ [35]. IL-8 and TNF- $\alpha$ could enhance the expression of S100A8 and S100A9 as a positive feedback loop [36]. Taken together, these findings may suggest an amplifying effect of S100A8 and S100A9 on the innate immune responses in the pathogenic mechanism of baker's asthma.

In addition, serum levels of MPO, IL- 8 , and TNF- $\alpha$ moderately correlated with serum S100A8 but weakly with serum S100A9 levels. These findings could be explained by the previous finding that S100A8 is the main active component while S100A9 serves as a regulator of the S100A8/S100A9 complex which activates TLR4 to induce IL- 8 and TNF- $\alpha$ production upon LPS stimulation [21].

Limitations of the present study are skewed distributions of the serum levels of the two $\$ 100$ proteins due to high levels of serum S100A8 and S100A9 in some study subjects. However, when we performed log transformation of these data to achieve normal distributions prior to statistical analyses, statistical significances were observed in both analyses with log-transformed and raw data (using parametric and nonparametric tests, respectively), which strengthens our findings in the present study.

In conclusion, this is the first study to demonstrate the involvement of serum S100A8 and S100A9 in the pathogenesis of baker's asthma probably by enhancing innate immune responses under the regulation of TLR4 polymorphisms. We also suggest that serum levels of S100A8 could be a potential biomarker for occupational allergen exposure in bakery workers.

\section{Acknowledgments}

We thank Prof. Dae Ryong Kang and Dr. Jayoun Kim (Office of Biostatistics, Ajou University School of Medicine) for providing professional suggestions in statistical analyses.

This study was supported by a grant of the Korean Health Technology R\&D Project, Ministry of Health \& Welfare, South Korea (H14C2628).

\section{Disclosure Statement}

The authors have no conflict of interest to declare.

\section{References}

1 Kwon SC, Song J, Kim YK, Calvert GM: Work-related asthma in Korea - findings from the Korea Work-Related Asthma Surveillance (KOWAS) program, 2004-2009. Allergy Asthma Immunol Res 2014;7:51-59.

2 Hur GY, Koh DH, Kim HA, Park HJ, Ye YM, Kim KS, et al: Prevalence of work-related symptoms and serum-specific antibodies to wheat flour in exposed workers in the bakery industry. Respir Med 2008;102:548-555.
3 Quirce S, Diaz-Perales A: Diagnosis and management of grain-induced asthma. Allergy Asthma Immunol Res 2013;5:348-356.

4 Marraccini P, Brass DM, Hollingsworth JW, Maruoka S, Garantziotis S, Schwartz DA: Bakery flour dust exposure causes non-allergic inflammation and enhances allergic airway inflammation in mice. Clin Exp Allergy 2008;38:1526-1535. 
5 Halayko AJ, Ghavami S: S100A8/A9: a mediator of severe asthma pathogenesis and morbidity? Can J Physiol Pharmacol 2009;87: 743-755.

6 Kang JH, Hwang SM, Chung IY: S100A8, S100A9, and S100A12 activate airway epithelial cells to produce MUC5AC via ERK and NF-kappaB pathways. Immunology 2014; 144:79-90.

7 Ehrchen JM, Sunderkotter C, Foell D, Vogl T, Roth J: The endogenous Toll-like receptor 4 agonist S100A8/S100A9 (calprotectin) as innate amplifier of infection, autoimmunity, and cancer. J Leukoc Biol 2009;86:557-566.

8 Lee TH, Jang AS, Park JS, Kim TH, Choi YS, Shin HR, et al: Elevation of S100 calcium binding protein A9 in sputum of neutrophilic inflammation in severe uncontrolled asthma. Ann Allergy Asthma Immunol 2013;111:268. e1-275.e1.

9 Fahy JV: Goblet cell and mucin gene abnormalities in asthma. Chest 2002;122:320S$326 \mathrm{~S}$.

10 Rose MC, Voynow JA: Respiratory tract mucin genes and mucin glycoproteins in health and disease. Physiol Rev 2006;86:245-278.

11 Edwards MR, Bartlett NW, Clarke D, Birrell M, Belvisi M, Johnston SL: Targeting the NFkappaB pathway in asthma and chronic obstructive pulmonary disease. Pharmacol Ther 2009;121:1-13.

12 Cho HJ, Kim SH, Kim JH, Choi H, Son JK, Hur GY, et al: Effect of Toll-like receptor 4 gene polymorphisms on work-related respiratory symptoms and sensitization to wheat flour in bakery workers. Ann Allergy Asthma Immunol 2011;107:57-64.

13 Gebhardt C, Nemeth J, Angel P, Hess J: S100A8 and S100A9 in inflammation and cancer. Biochem Pharmacol 2006;72:16221631.

14 Donato R, Cannon BR, Sorci G, Riuzzi F, Hsu $\mathrm{K}$, Weber DJ, et al: Functions of $\mathrm{S} 100$ proteins. Curr Mol Med 2013;13:24-57.

15 Yui S, Nakatani Y, Mikami M: Calprotectin (S100A8/S100A9), an inflammatory protein complex from neutrophils with a broad apoptosis-inducing activity. Biol Pharm Bull 2003; 26:753-760.
16 Aoki T, Matsumoto Y, Hirata K, Ochiai K, Okada M, Ichikawa K, et al: Expression profiling of genes related to asthma exacerbations. Clin Exp Allergy 2009;39:213-221.

17 Goyette J, Geczy CL: Inflammation-associated S100 proteins: new mechanisms that regulate function. Amino Acids 2011;41:821-842.

18 Cornish CJ, Devery JM, Poronnik P, Lackmann M, Cook DI, Geczy CL: S100 protein CP-10 stimulates myeloid cell chemotaxis without activation. J Cell Physiol 1996;166: 427-437.

19 Brisman J: Baker's asthma. Occup Environ Med 2002;59:498-502; quiz 426, 502.

20 Smith TA, Smith PW: Respiratory symptoms and sensitization in bread and cake bakers. Occup Med (Lond) 1998;48:321-328.

21 Vogl T, Tenbrock K, Ludwig S, Leukert N, Ehrhardt C, van Zoelen MA, et al: Mrp8 and Mrp14 are endogenous activators of Toll-like receptor 4, promoting lethal, endotoxin-induced shock. Nat Med 2007;13:1042-1049.

22 Domanska A, Stroszejn-Mrowca G: Endotoxin in the occupational environment of bakers: method of detection. Int J Occup Med Environ Health 1994;7:125-134.

$23 \mathrm{Xu} \mathrm{K}$, Geczy CL: IFN-gamma and TNF regulate macrophage expression of the chemotactic S100 protein S100A8. J Immunol 2000; 164:4916-4923.

24 Endoh Y, Chung YM, Clark IA, Geczy CL, Hsu K: IL-10-dependent S100A8 gene induction in monocytes/macrophages by doublestranded RNA. J Immunol 2009;182:22582268.

25 Xu K, Yen T, Geczy CL: IL-10 up-regulates macrophage expression of the $\mathrm{S} 100$ protein S100A8. J Immunol 2001;166:6358-6366.

26 Haegens A, Vernooy JH, Heeringa P, Mossman BT, Wouters EF: Myeloperoxidase modulates lung epithelial responses to pro-inflammatory agents. Eur Respir J 2008;31:252-260.

27 Monteseirin J, Bonilla I, Camacho J, Conde J, Sobrino F: Elevated secretion of myeloperoxidase by neutrophils from asthmatic patients: the effect of immunotherapy. J Allergy Clin Immunol 2001;107:623-626.

28 Raquil MA, Anceriz N, Rouleau P, Tessier PA: Blockade of antimicrobial proteins S100A8 and S100A9 inhibits phagocyte migration to the alveoli in streptococcal pneumonia. J Immunol 2008; 180:3366-3374.
29 Yan L, Mathew L, Chellan B, Gardner B, Earley J, Puri TS, et al: S100/calgranulin-mediated inflammation accelerates left ventricular hypertrophy and aortic valve sclerosis in chronic kidney disease in a receptor for advanced glycation end products-dependent manner. Arterioscler Thromb Vasc Biol 2014; 34:1399-1411.

30 Boyum A, Skrede KK, Myhre O, Tennfjord VA, Neurauter CG, Tolleshaug H, et al: Calprotectin (S100A8/S100A9) and myeloperoxidase: co-regulators of formation of reactive oxygen species. Toxins (Basel) 2010;2:95115.

31 Liu G, Zhu R, Li B: TNF-alpha and IL-8 of the patients with allergic asthma. J Huazhong Univ Sci Technolog Med Sci 2005;25:274275, 309 .

32 Silvestri M, Bontempelli M, Giacomelli $\mathrm{M}$, Malerba M, Rossi GA, Di Stefano A, et al: High serum levels of tumour necrosis factoralpha and interleukin- 8 in severe asthma: markers of systemic inflammation? Clin Exp Allergy 2006;36:1373-1381.

33 Ahmad A, Bayley DL, He S, Stockley RA: Myeloid related protein-8/14 stimulates interleukin-8 production in airway epithelial cells. Am J Respir Cell Mol Biol 2003;29:523-530.

34 Sunahori K, Yamamura M, Yamana J, Takasugi $\mathrm{K}$, Kawashima M, Yamamoto $\mathrm{H}$, et al: The S100A8/A9 heterodimer amplifies proinflammatory cytokine production by macrophages via activation of nuclear factor kappa $\mathrm{B}$ and p38 mitogen-activated protein kinase in rheumatoid arthritis. Arthritis Res Ther 2006;8:R69.

35 Kerkhoff C, Eue I, Sorg C: The regulatory role of MRP8 (S100A8) and MRP14 (S100A9) in the transendothelial migration of human leukocytes. Pathobiology 1999;67:230-232.

36 Nukui T, Ehama R, Sakaguchi M, Sonegawa H, Katagiri C, Hibino T, et al: S100A8/A9, a key mediator for positive feedback growth stimulation of normal human keratinocytes. J Cell Biochem 2008;104:453-464. 